\title{
Management of Patients With Metastatic Renal Cell Cancer and Bone Metastases
}

\author{
CARSTEN NIEDER $^{1,2}$, ASTRID DALHAUG $^{1,2}$ and ADAM R. PAWINSKI ${ }^{1}$ \\ ${ }^{1}$ Department of Oncology and Palliative Medicine, Nordland Hospital, Bod $\phi$, Norway; \\ ${ }^{2}$ Department of Clinical Medicine, Faculty of Health Sciences, University of Troms $\phi$, Troms $\phi$, Norway
}

\begin{abstract}
Background/Aim: Previous research has suggested that patients with metastatic renal cell cancer $(m R C C)$ and bone metastases have a poorer prognosis compared to their counterparts with no skeletal involvement. Therefore, we analyzed the management and outcomes of such patients in our center. Patients and Methods: We performed a retrospective study of 35 consecutive patients who received systemic treatment, largely targeted therapy, for mRCC with bone metastases. Results: The median overall survival was 25 months from the time of diagnosis of $m R C C$. The 5-year survival rate was $16 \%$. Survival from diagnosis of $m R C C$ was significantly worse in patients with bone metastases present at the start of first-line systemic therapy (median 13 months) compared to delayed metastases diagnosed later during the course of disease $(46$ months, $p=0.01)$. Few patients (29\%) were able to receive more than two lines of systemic therapy. Bone-only metastases were uncommon (11\%). Conclusion: Most patients with mRCC and bone metastases have limited overall survival.
\end{abstract}

Metastatic lesions from renal cell carcinoma (RCC) are often located in the lungs, distant lymph nodes, liver or bones (1). Besides causing pain and skeletal-related events (SRE), the presence of bone metastases has been associated with reduced overall survival $(2,3)$. Systemic therapy options for patients with metastatic RCC (mRCC) currently include tyrosine kinase inhibitors (targeted therapy), which target vascular endothelial growth factor receptors (VEGFR), mammalian target of rapamycin (mTOR) and other pathways (4-8). In addition, monoclonal antibodies, such as bevacizumab,

This article is freely accessible online.

Correspondence to: Carsten Nieder, Department of Oncology and Palliative Medicine, Nordland Hospital, 8092 Bod $\varnothing$, Norway. Tel: +47 75578449, Fax: +47 75534975, e-mail: carsten.nieder@nlsh.no

Key Words: Metastatic renal cell cancer, systemic therapy, prognosis, bone metastases, rural care. pembrolizumab, ipilimumab and nivolumab, have yielded positive results (9-11). Cabozantinib is one of several approved treatment options, which has been studied specifically in the subgroup of patients with bone metastases, based on data from the METEOR trial (12). In this analysis, patient outcomes were significantly better after cabozantinib compared to everolimus. For example, the median overall survival was 20 vs. 12 months. Due to these considerations, we performed a retrospective quality of care study addressing the management and outcomes of patients with bone metastases from mRCC. The setting of this study is in a rural region in northern Norway where all oncologists are located at a single public hospital and adherence to national treatment guidelines is high $(13,14)$.

\section{Patients and Methods}

All patients were covered by the national Norwegian health care system and received standard treatment according to national guidelines outside of clinical trials or early access programs. We used the hospital's electronic patient records to identify all patients with mRCC managed with systemic therapy between 2006 and 2018 $(n=72)$. Baseline characteristics, treatment and date of death or last contact were abstracted. All patients with bone metastases on staging or follow-up computed tomography (CT) scans were included $(n=35)$. Prognosis was estimated according to the Memorial Sloan Kettering Cancer Center (MSKCC) model, which includes performance status (PS), time interval, serum hemoglobin, calcium and lactate dehydrogenase (15). Actuarial overall survival was calculated (Kaplan-Meier method) and compared between different groups using the log-rank test. The date of the image-based diagnosis of mRCC was defined as the start date. Two patients were censored at the date of last contact after 39 and 124 months, respectively. Date of death was recorded in all remaining 33 patients. Parameters with log-rank $p$-Value $<0.1$ were included in a multivariate Cox regression analysis. Statistical analyses were performed using IBM SPSS Statistics 25 (IBM Corp., Armonk, NY, USA).

\section{Results}

Baseline characteristics. The majority of patients had clear cell histology (83\%), male gender $(77 \%)$, age between 60 and 69 years $(74 \%)$, distant metastases at the time of initial 


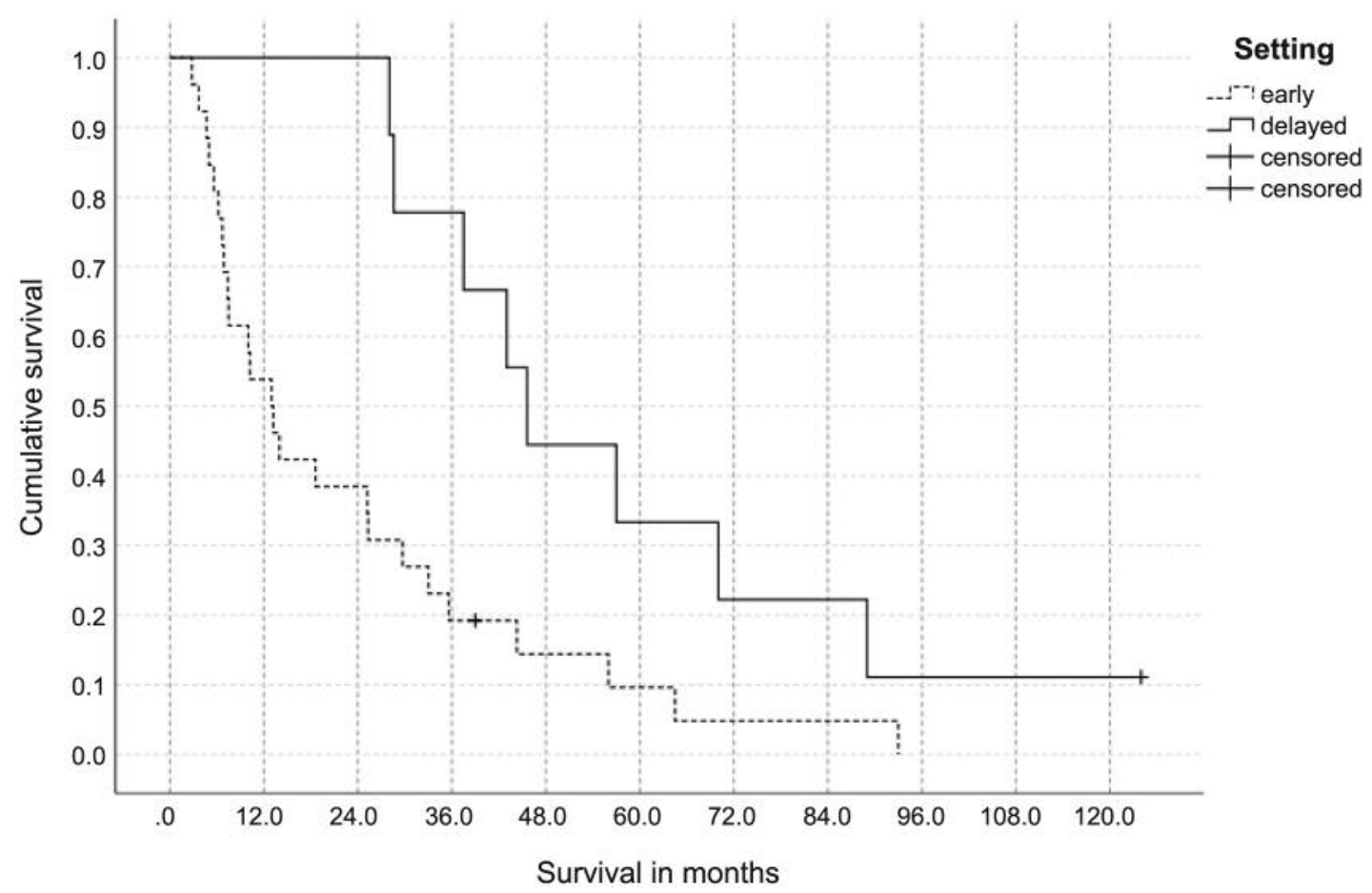

Figure 1. Actuarial overall survival of patients with bone metastases at the time of systemic first-line treatment (early, $n=26)$ and patients with bone metastases later during the course of the disease (delayed, $n=9)$. Their median survival is 13 and 46 months, respectively $(p=0.01)$.

diagnosis with RCC (63\%), and bone metastases at the time of first-line systemic therapy (74\%). Bone-only metastases were present in four patients $(11 \%)$. Commonly $(60 \%)$, at least two different extra-skeletal sites were involved, e.g. liver and lungs. Eleven patients (31\%) had brain metastases. Twenty-four patients $(69 \%)$ had been managed with nephrectomy. First-line treatment consisted of: i) sunitinib (28 patients, 80\%), ii) pazopanib (3 patients, 9\%), and iii) others (4 patients, $11 \%)$. Twenty-one patients (60\%) received at least one additional line of systemic therapy (second-line everolimus in 10), and 10 patients (29\%) received at least three different lines. Baseline Eastern Cooperative Oncology Group (ECOG) PS was 0,1 and 2 in 23, 40 and $37 \%$, respectively. Seven patients $(20 \%)$ were in the MSKCC good, 19 patients in the intermediate $(54 \%)$, and 9 in the poor prognosis category (26\%).

Actuarial overall survival. The median overall survival was 25 months from the time of diagnosis of mRCC (all 35 patients). The 5-year survival rate was $16 \%$. Survival from the time of diagnosis of mRCC was significantly worse in patients with bone metastases present at the start of first-line systemic therapy (median $=13$ months) compared to delayed metastases ( 46 months, $p=0.01$ ), as shown in Figure 1. The age-related difference was not significant ( 29 months if $<60$ years vs. 19 months if older, $p=0.06)$. The presence of additional brain metastases was associated with a significantly shorter survival (7 vs. 29 months, $p=0.03$ ). Nephrectomy was associated with a better survival (30 vs. 13 months, $p=0.03$ ). The same was true for better ECOG PS (57, 14 and 10 months, $p=0.003$ ). The difference between the three MSKCC prognostic strata did not reach statistical significance $(37.5,28$ and 10 months, $p=0.2)$.

Separate analyses were performed for the subgroup of patients with bone metastases present at the time of first-line systemic therapy. In univariate tests, the following parameters predicted better survival: i) male gender $(p=0.03)$, ii) no brain metastases $(p=0.04)$, iii) bone-only or maximum one extra-skeletal organ involved $(p=0.03)$, and iv) ECOG PS $0(p=0.001)$. In the multivariate model, male gender was the only significant prognostic factor $(p=0.05)$.

\section{Discussion}

This retrospective study assessed the outcomes of systemic therapy in 35 patients with mRCC and bone involvement. Typical patients were in their 60s, had clear cell histology, additional extra-skeletal metastases and intermediate prognostic features, according to the MSKCC model. The most common first-line systemic therapy consisted of 
sunitinib $(7,16,17)$, and $60 \%$ proceeded to second-line treatment. Other treatments, such as bone surgery or radiotherapy were used as clinically needed. Use of bisphosphonates or denosumab was very uncommon in our clinical practice. Most patients $(74 \%)$ had developed bone metastases already before they started with the first-line systemic therapy. The remaining patients developed bone metastases later during the course of their disease. A large proportion of patients $(63 \%)$ had synchronous distant metastases at the time of detection of RCC. The presence of bone metastases at the start of the first-line treatment resulted in significantly shorter survival compared to the development of bone metastases at later points in time. While a shorter survival was observed in the univariate log-rank tests for the presence of brain metastases, ECOG PS and others, the multivariate regression analysis did not confirm these results. Male gender was the only independent prognostic factor. Overall median survival was 25 months, comparable to the study by Ruatta et al. (23 months, 300 patients) (18).

McKay et al. have conducted a review from the International Metastatic Renal Cell Carcinoma Database Consortium (IMDC) of 2027 patients with mRCC (3). The presence of bone metastases in these patients was $34 \%$ overall, and when stratified by IMDC risk groups it was $27 \%, 33 \%$, and $43 \%$ in the favorable-, intermediate-, and poor-risk groups, respectively $(p<0.001)$. When patients were classified based on the presence of bone metastases, the hazard ratio, adjusted for IMDC risk factors, was 1.4 (95\% confidence interval=1.2-1.6). The median survival from the start of targeted therapy was 14.9 months (13 months in the present, however, much smaller study). The prediction model performance for the overall survival was significantly improved when bone and also liver metastases were added to the IMDC prognostic model.

In the METEOR study, the median survival of patients with bone metastases was 20 months in the cabozantinib arm and 12 months in the everolimus arm in the second or higher-line setting (12). Comparable differences were seen if both bone and visceral metastases were present. The relatively long survival in this study can be explained by the inclusion criteria employed. In the real-world setting, many patients violate these criteria and are not eligible for trial inclusion $(13,19-21)$. In the present retrospective study, only one patient received second-line cabozantinib. However, seven patients were treated with everolimus. Their median overall survival was 7 months. Given that new first-line treatment options already have been approved, additional studies assessing different treatment sequences are urgently needed.

When interpreting our results, several limitations in the study design should be taken into consideration, e.g. the retrospective analysis and the limited number of patients. We did not record time to progression, adverse events, hypercalcemia and SREs. Finally, the subgroup of patients who developed bone metastases later during the course of disease was too small to perform meaningful analyses. The optimal integration of local treatment, such as surgery or stereotactic radiotherapy, especially in patients with few metastatic lesions, is a topic of ongoing research $(22,23)$. In principle, such approaches may contribute to bone stability, reduced symptoms and better disease control.

In conclusion, the results from our study confirm that most patients with bone metastases from RCC have a limited overall survival. Better systemic treatment options are needed for such patients. Subgroup analyses of the pivotal studies that have led to approval of new drug combinations, which often include immune checkpoint inhibitors, should be performed to clarify their impact in patients with bone metastases.

\section{Conflicts of Interest}

The Authors declare that they have no conflicts of interest.

\section{Authors' Contributions}

CN participated in the design of the study and performed the statistical analysis. $\mathrm{AD}, \mathrm{ARP}$ and $\mathrm{CN}$ collected patient data. $\mathrm{CN}$, and AD conceived of the study and drafted the manuscript. All Authors read and approved the final manuscript.

\section{References}

1 Guida A, Escudier B and Albiges L: Treating patients with renal cell carcinoma and bone metastases. Expert Rev Anticancer Ther 18(11): 1135-1143, 2018. PMID: 30183421. DOI: 10.1080/ 14737140.2018 .1520097

2 Woodward E, Jagdev S, McParland L, Clark K, Gregory W, Newsham A, Rogerson S, Hayward K, Selby P and Brown J: Skeletal complications and survival in renal cancer patients with bone metastases. Bone 48(1): 160-166, 2011. PMID: 20854942. DOI: $10.1016 /$ j.bone 2010.09 .008

3 McKay RR, Kroeger N, Xie W, Lee JL, Knox JJ, Bjarnason GA, MacKenzie MJ, Wood L, Srinivas S, Vaishampayan UN, Rha SY, Pal SK, Donskov F, Tantravahi SK, Rini BI, Heng DY and Choueiri TK: Impact of bone and liver metastases on patients with renal cell carcinoma treated with targeted therapy. Eur Urol 65(3): 577-584, 2014. PMID: 23962746. DOI: 10.1016/ j.eururo.2013.08.012

4 Motzer RJ, Hutson TE, Cella D, Reeves J, Hawkins R, Guo J, Nathan P, Staehler M, de Souza P, Merchan JR, Boleti E, Fife $\mathrm{K}$, Jin J, Jones R, Uemura H, De Giorgi U, Harmenberg U, Wang J, Sternberg CN, Deen K, McCann L, Hackshaw MD, Crescenzo R, Pandite LN and Choueiri TK: Pazopanib versus sunitinib in metastatic renal-cell carcinoma. N Engl J Med 369(8): 722-731, 2013. PMID: 23964934. DOI: 10.1056/ NEJMoa1303989

5 Choueiri TK, Escudier B, Powles T, Mainwaring PN, Rini BI, Donskov F, Hammers H, Hutson TE, Lee JL, Peltola K, Roth BJ, Bjarnason GA, Géczi L, Keam B, Maroto P, Heng DY, 
Schmidinger M, Kantoff PW, Borgman-Hagey A, Hessel C, Scheffold C, Schwab GM, Tannir NM and Motzer RJ: Cabozantinib versus everolimus in advanced renal-cell carcinoma. N Engl J Med 373(19): 1814-1823, 2015. PMID: 26406150. DOI: 10.1056/NEJMoa1510016

6 Beisland C, Johannesen TB, Klepp O, Axcrona U, Torgersen KM, Kowalski J, Solli O, Sandin R and Oldenburg J: Overall survival in renal cell carcinoma after introduction of targeted therapies: a Norwegian population-based study. Onco Targets Ther 10: 371-385, 2017. PMID: 28144152. DOI: 10.2147/ OTT.S123061

7 Motzer RJ, Hutson TE, Tomczak P, Michaelson MD, Bukowski RM, Oudard S, Negrier S, Szczylik C, Pili R, Bjarnason GA, Garcia-del-Muro X, Sosman JA, Solska E, Wilding G, Thompson JA, Kim ST, Chen I, Huang $X$ and Figlin RA: Overall survival and updated results for sunitinib compared with interferon alfa in patients with metastatic renal cell carcinoma. J Clin Oncol 27(22): 3584-3590, 2009. PMID: 19487381. DOI: $10.1200 /$ JCO.2008.20.1293

8 Vuorinen RL, Paunu N, Turpeenniemi-Hujanen T, Reunamo T, Jekunen A, Kataja V, Sintonen H, Purmonen T and KellokumpuLehtinen PL: Sunitinib first-line treatment in metastatic renal cell carcinoma: Costs and effects. Anticancer Res 39(10): 55595564, 2019. PMID: 31570450. DOI: 10.21873/anticanres.13749

9 Motzer RJ, Escudier B, McDermott DF, George S, Hammers HJ, Srinivas S, Tykodi SS, Sosman JA, Procopio G, Plimack ER, Castellano D, Choueiri TK, Gurney H, Donskov F, Bono P, Wagstaff J, Gauler TC, Ueda T, Tomita Y, Schutz FA, Kollmannsberger C, Larkin J, Ravaud A, Simon JS, Xu LA, Waxman IM and Sharma P: Nivolumab versus everolimus in advanced renal-cell carcinoma. N Engl J Med 373(19): 18031813, 2015. PMID: 26406148. DOI: 10.1056/NEJMoa1510665

10 Chang AJ, Zhao L, Zhu Z, Boulanger K, Xiao H, Wakefield MR, Bai $Q$ and Fang Y: The past, present and future of immunotherapy for metastatic renal cell carcinoma. Anticancer Res 39(6): 2683-2687, 2019. PMID: 31177102. DOI: 10.21873/anticanres.13393

11 Schultze-Seemann W, Schulz H, Tschechne B and Häckl M: Bevacizumab plus IFN-alpha-2a in first-line treatment of patients with advanced or metastatic renal cell carcinoma: A prospective German non-interventional study. Anticancer Res 39(2): 875-882, 2019. PMID: 30711970. DOI: 10.21873/ anticanres. 13188

12 Escudier B, Powles T, Motzer RJ, Olencki T, Arén Frontera O, Oudard S, Rolland F, Tomczak P, Castellano D, Appleman LJ, Drabkin H, Vaena D, Milwee S, Youkstetter J, Lougheed JC, Bracarda S and Choueiri TK: Cabozantinib, a new standard of care for patients with advanced renal cell carcinoma and bone metastases? Subgroup analysis of the METEOR trial. J Clin Oncol 36(8): 765-772, 2018. PMID: 29309249. DOI: $10.1200 / J C O .2017 .74 .7352$

13 Nieder C, Syed MA, Dalhaug A, Pawinski A and Norum J: Eligibility for phase 3 clinical trials of systemic therapy in realworld patients with metastatic renal cell cancer managed in a rural region. Med Oncol 34(9): 149, 2017. PMID: 28748331. DOI: $10.1007 / \mathrm{s} 12032-017-1002-6$
14 Nieder C, Spanne O, Nordøy T and Dalhaug A: Treatment of brain metastases from renal cell cancer. Urol Oncol 29(4): 405410, 2011. PMID: 19854078. DOI: 10.1016/j.urolonc. 2009.07.004

15 Motzer RJ, Bacik J and Mazumdar M: Prognostic factors for survival of patients with stage IV renal cell carcinoma: Memorial Sloan-Kettering Cancer Center experience. Clin Cancer Res 10(18): 6302S-6303S, 2004. PMID: 15448021. DOI: 10.1158/1078-0432.CCR-040031

16 Choueiri TK and Motzer RJ: Systemic therapy for metastatic renal-cell carcinoma. N Engl J Med 376(4): 354-366, 2017. PMID: 28121507. DOI: 10.1056/NEJMra1601333

17 Norum J, Nieder C and Kondo M: Sunitinib, sorafenib, temsirolimus or bevacizumab in the treatment of metastatic renal cell carcinoma: a review of health economic evaluations. J Chemother 22(2): 75-82, 2010. PMID: 20435564. DOI: 10.1179/joc.2010.22.2.75

18 Ruatta F, Derosa L, Escudier B, Colomba E, Guida A, Baciarello G, Loriot Y, Fizazi K and Albiges L: Prognosis of renal cell carcinoma with bone metastases: Experience from a large cancer centre. Eur J Cancer 107: 79-85, 2019. PMID: 30551078. DOI: 10.1016/j.ejca.2018.10.023

19 Mitchell AP, Harrison MR, Walker MS, George DJ, Abernethy AP and Hirsch BR: Clinical trial participants with metastatic renal cell carcinoma differ from patients treated in real-world practice. J Oncol Pract 11(6): 491-497, 2015. PMID: 26330533. DOI: $10.1200 / J O P .2015 .004929$

20 Keizman D, Rouvinov K, Sella A, Gottfried M, Maimon N, Kim JJ, Eisenberger MA, Sinibaldi V, Peer A, Carducci MA, Mermershtain W, Leibowitz-Amit R, Weitzen R and Berger R: Is there a "trial effect" on outcome of patients with metastatic renal cell carcinoma treated with sunitinib? Cancer Res Treat 48(1): 281-287, 2016. PMID: 25761478. DOI: $10.4143 / \mathrm{crt}$. 2014.289

21 Schwab M, Hofmann R, Heers H and Hegele A: mRCC outcome in the treatment of metastatic renal cell carcinoma - A German single-center real-world experience. In Vivo 32(6): 1617-1622, 2018. PMID: 30348724. DOI: 10.21873/invivo.11422

22 Grünwald V, Eberhardt B, Bex A, Flörcken A, Gauler T, Derlin T, Panzica M, Dürr HR, Grötz KA, Giles RH, von Falck C, Graser A, Muacevic A and Staehler M: An interdisciplinary consensus on the management of bone metastases from renal cell carcinoma. Nat Rev Urol 15(8): 511-521, 2018. PMID: 29904105. DOI: 10.1038/s41585-018-0034-9

23 Nieder C, Pawinski A and Dalhaug A: Continuous controversy about radiation oncologists' choice of treatment regimens for bone metastases: should we blame doctors, cancer-related features, or design of previous clinical studies? Radiat Oncol 8: 85, 2013. PMID: 23574944. DOI: 10.1186/1748-717X-8-85

Received November 29, 2019

Revised December 11, 2019

Accepted December 16, 2019 